\title{
PENDAMPINGAN DAN PEMANFAATAN HERBAL UNTUK MENINGKATAN PRODUKSI DAN KUALITAS SUSU SAPI PERAH
}

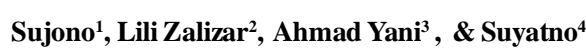

1.2,3,4 Jurusan Produksi Ternak, Fakultas Pertanian Peternakan, Universitas Muhammadiyah Malang Alamat Korespondensi : Jln. Raya Tlogoma, No.246 Malang

Email: sujono_umm64@yahoo.com, lilizalizarthahir@yahoo.com, ayani_lpm_umm@yahoo.com

\section{ABSTRAK}

Desa Pandesari merupakan salah satu desa di wilayah Kecamatan Pujon, berada pada ketinggian berkisar 1.000 s.d. 1.200 meter dpl, suhu udara di kecamatan Pujon cukup dingin $18-23^{\circ} \mathrm{C}$, curah hujan sekitar $1000 \mathrm{~mm} / \mathrm{thn}$ sangat sesuai untuk pengembangan sapi perah baik dari kondisi suhu/ kelembaban serta potensi ketersediaan hijauan makanan ternak. Lahan umumnya subur dengan sumber air yang melimpah dari Coban Rondo sehingga Desa Pandesari sangat cocok untuk usaha sapi perah dan sayur mayur yang memberikan kontribusi besar bagi Koperasi Susu Pujon maupun Pasar Agrobi Mantung. Jumlah anggota kelompok peternak "ANJASMORO AGRI LESTARI" yang menjadi Mitr Program Pengabdian ini berlokasi di Desa Pandesari sebanyak 21 orang dengan jumlah ternak sap perah 163 ekor. Kelompok Mitra ini didirikan tanggal 29 Desember 2008.

Permasalahan yang sering muncul pada kelompok Mitra Program Pengabdian ini adalah : sering terjadi kelumpuhan induk yang baru melahirkan dengan potensi produksi susu tinggi. Hal ini terjadi karena rendahnya konsumsi mineral selama kebuntingan. Sementara selama kebuntingan, terus dilakukan pemerahan yang menyedot mineral yang ada dalam tubuh terutama pada tulang dan gig apabila pasokan dari pakan kurang. Permasalahan lain adalah kasus kecacingan pada pedet. Kecacingan pada ternak muda dapat menyebabkan hambatan pertumbuhan, penurunan berat badan dan kematian. Pencegahan penyakit kecacingan dilakukan dengan memberikan pengetahuan kepada peternak tentang media penularan penyakit dan pemberian obat berbahan herbal yang bisa dibuat oleh peternak sendiri. Peternak sapi perah di Desa Pandesari tidak cukup memiliki pendidikan yang mampu menunjang dalam usaha ternak sapi perah. Pendidikan kecakapan hidup (life Skills) dengan pendekatan berbasi kebutuhan masyarakat luas (broad based education) adalah pilihan tepat dalam pengembangan usaha sapi perah.

Berdasarkan potensi dan permasalahan yang dihadapi kelompok peternak di Desa Pandesar yang dijadikan sasaran kegiatan Pendampingan dalam upaya meningkatkan pendapatan peternak sap perah dan mendukung Kabupaten Malang sebagai Sentra Sapi Perah Nasional di Jawa Timur serta pemahaman masyarakat terhadap pembangunan yang berkelanjutan semakin baik melalui pendampinga suplementasi mineral yang seimbang dan pencegahan serta pengobatan penyakit berbahan herbal.

Hasil pelaksanaan kegiatan menunjukkan respon masyarakat yang tinggi terhadap kegiatan pelaksanaan penyuluhan, pelatihan/pendampingan pada : manajemen usaha sapi perah, penanganan dan pencegahan penyakit dengan bahan herbal, peranan mineral, seleksi bibit sapi perah dan penanganan limbah telah berjalan sesuai dengan harapan. Masyarakat telah dapat merubah pola sistem pemeliharaan sapi perah menjadi lebih intensif dengan pengedepankan sistem manajemen berwawasan lingkungan dan telah mampu meningkatkan harapan dan pendapatan peternak sapi perah di kelompok peternak sapi perah “Anjasmoro Agri Lestari”'Desa Pandesari.

Perlu dilakukan pendampingan berkelanjutan secara berkala bagi peternak sapi perah agar lebih mampu menguasai teknologi tepat guna dalam usaha sapi perah berwawasan lingkungan.

Kata kunci : Herbal, Produksi dan kualitas, Susu sapi

\section{PENDAHULUAN}

Desa Pandesari merupakan salah satu desa di wilayah Kecamatan Pujon Kabupaten Malang yang

36 Dedikasi, Volume 9, Mei 2012: 36 - 46 terdiri dari lahan sawah $40 \%$, lahan pekarangan $5 \%$ dan lahan hutan sekitar $55 \%$. Desa Pandesari berad pada ketinggian berkisar 1.000 s.d. 1.200 meter dpl, suhu udara di Kecamatan Pujon cukup dingin 18 $23^{\circ} \mathrm{C}$, curah hujan sekitar $1000 \mathrm{~mm} / \mathrm{thn}$ sangat sesua untuk pengembangan sapi perah baik dari kondisi suhu/ kelembaban serta potensi ketersediaan hijauan makanan ternak. Lahan umumnya subur dengan sumber air yang melimpah dari Coban Rondo.

Jumlah anggota kelompok peternak "ANJASMORO AGRI LESTARI" yang menjadi Mitra Program Pengabdian ini berlokasi di Desa Pandesari sebanyak 21 orang dengan jumlah ternak sapi perah 163 ekor. Kelompok Mitra ini didirikan tanggal 29 Desember 2008, yang dirintis melalui program Sarjana Membangun Desa (SMD) dengan jumlah awal sebanyak 60 ekor sapi perah.

Peternak Desa Pandesari belum sepenuhnya mendapatkan pembinaan secara berkesinambungan Dinas Peternakan maupun Perguruan Tinggi da cenderung berjalan sendiri-sendiri sesuai dengan kemampuan masing-masing peternak sehingg produksi susu rata-rata hanya sekitar 8 - 10 liter/ekor/ hari, tetapi apabila dilakukan perbaikan manajemen dan dikembangkan dengan baik melalui pendampinga secara kontinu dari Dinas Peternakan maupu Perguruan Tinggi maka produksi dapat ditingkatkan menjadi lebih dari 12 liter/ekor/hari.

Permasalahan yang sering muncul pada kelompok peternak sapi perah di Kecamatan Pujon adalah : Pertama seringnya terjadi kelumpuhan pada induk yang baru melahirkan yang memiliki potens produksi susu tinggi. Hal ini terjadi karena rendahny konsumsi mineral selama kebuntingan. Sementara selama kebuntingan tersebut, terus menerus dilakukan pemerahan yang menyedot sejumlah besar minera yang ada dalam tubuh terutama pada tulang dan gigi apabila pasokan dari pakan kurang.

Permasalah kedua adalah kasus mastitis yang menyerang hampir $80 \%$ induk yang dimiliki peternak yang menyebabkan kerugian sampai $30 \%$ dari total produksi, karena susu induk yang menderita mastitis seluruhnya dibuang. Padahal bisa dilakukan pencegahan dengan menggunakan bahan alami yang murah dan mudah didapat yang dibuat salep atau ointment, dengan cara dioleskan pada puting setiap kali setelah diperah. Permasalahan lainnya adalah kasus kecacingan pada pedet. Kecacingan pada ternak muda dapat menyebabkan hambatan pertumbuhan, penurunan berat badan dan kematian. Mengingat berbagai permasalahan tersebut, maka perlu dilakukan peternak. Pencegahan penyakit dapat dilakukan dengan memberikan pengetahuan tentang media penularan penyakit, cara-cara penularan penyakit serta pemberian obat-obat berbahan herbal yang bisa dilakukan peternak sendiri untuk mencegah penyakit.

\section{Permasalah Mitra}

Para peternak sapi perah di Desa Pandesari Kecamatan Pujon melaksanakan usaha sapi perah secara turun temurun dengan keuntungan yang sangat tidak memadai karena berbagai permasalahan dalam dan pendampingan berkelanjutan baik dina Pemerintahan maupun Perguruan Tinggi maka peternak kembali menjalankan usahanya secara sendiri-sendiri dengan manajemen seadanya. Berdasarkan hasil diskusi dengan anggota peternak diperoleh beberapa permasalahan yang dihadapi sebagai berikut

1. Produksi susu masih rata-rata relatif rendah yaitu tidak lebih dari 10 ltr/ekor/hari dengan kualitas susu yang masih di atas grade 2 (karena jumlah mikroba di atas $3 \mathrm{juta} / \mathrm{ml}$, TS kurang dari $11 \%$ dan BJ tidak lebih dari 2,6)

2. Teknik pemberian mineral dilakukan berdasarkan perkiraan saja tanpa mengetahui kebutuhan ternak sesuai kondisi fisiologisnya sehingga tidak sesuai dengan kebutuhan masing-masing individu sapi perah.

3. Kasus penyakit mastitis tinggi (di atas $80 \%$ ) akibat sanitasi yang tidak bagus.

4. Susu yang tercampur antibiotik cukup tinggi, dimana setiap bulan pasti ada pengembalian susu yang tercemar antibiotik dari Industri Pengolah Susu

5. Tingkat kematian pedet relatif tinggi (lebih dari $5 \%$ ), akibat terkena penyakit.

Untuk membantu mengatasi permasalahan tersebut, maka perlu pendampingan dan pembinaan hingga mandiri dan menjaga keberlanjutan usahanya. Melalui program pendampingan ini diharapkan pula adanya inovasi dan transfer teknologi yang lebih tepat 
guna (TTG) dalam usaha budidaya Sapi Perah erutama penggunaan obat anti mastitis berbahan baku herbal, yang pada gilirannya akan mampu meningkatkan produktivitas sapi perah dan pendapatan para peternak.

\section{Tujuan}

Merujuk pada permasalahan yang dihadapi oleh kelompok peternak sapi perah "Desa Pandesari” maka adapun tujuan yang diharapkan adalah

1. Peternak menguasai sistem usaha peternakan yang intensif dan efisien terutama dalam pengendalian penyakit

2. Peternak dapat mengaplikasikan pemberian mineral yang tepat sesuai kondisi fisiologis ternak sehingga menjamin kesehatan dan produktifitas ternak.

3. Peternak terampil dalam mengaplikasikan teknologi pencegahan penyakit mastitis dengan bahan baku herbal sehingga relatif tidak mempunyai efek samping yang merugikan.

4. Meningkatnya pengetahuan dalam hal pencegahan penyakit mastitis dan penanganan induk sapi perah yang terkena mastitis.

5. Terwujudnya kelompok usaha sapi perah yang memiliki kemandirian dan mampu bekerjasama dengan prinsip saling menguntungkan dengan pihak lain

\section{METODE PELAKSANAAN}

\section{Kerangka Pemecahan Masalah}

Permasalahan utama peternak Sapi Perah Desa Pandesari adalah sering timbulnya kejadian mastitis pada sapi perah produksi dan terjadi kelumpuhan yang menyebabkan rata-rata produksi susu kurang dari 10 liter, kurangnya keterampilan dalam penyajian mineral serta teknik pemberian pakan, kesehatan ternak kurang diperhatikan, harga susu yang rendah kurang dari Rp. 3.400/liter dan belum dilaksanakannya manajemen usaha dengan baik. Oleh karena itu usulan pemecahan masalah sebagai berikut:

38 Dedikasi, Volume 9, Mei 2012:36- 46
1. Memberikan pendidikan dan penyuluhan tentang pentingnya sistem pengelolaan peternakan yang efektif dan efisien.

2. Pendampingan pada kelompok peternak dalam penyajian mineral sesuai kondisi fisiologis ternak sehingga tetap dalam kondis sehat dan produktifitas tetap tinggi.

3. Pendampingan pada peternak dalam mengaplikasikan pencegahan penyakit mastitis dengan bahan herbal sehingga relatif tidak berefek merugikan kesehatan manusia.

4. Pelatihan pada peternak dalam hal pencegahan penyakit mastitis dan penanganan induk sapi perah terken mastitis, penyusunan konsentrat yan ekonomis, pemilihan bibit ternak, dan pengolahan limbah untuk pertanian organik.

\section{Realisasi Pemecahan Masalah}

Untuk mencapai sasaran sesuai dengan tujuan ang telah direncanakan maka telah dilaksanakan kegiatan sebagai berikut :

1. Telah dilaksanakan penyuluhan tentang pentingnya sistem pengelolaan peternakan yang efektif dan efisien guna meningkatkan pendapatan peternak.

2. Telah diselenggarakan pendampingan kelompok peternak tentang cara penyajian mineral yang sesuai dengan kondisi fisiologis ternak sehingga ternak tetap sehat dan produktifitas tetap tinggi.

3. Telah dilaksanakan pendampingan peternak mengaplikasikan teknologi pencegahan penyakit mastitis dengan bahan baku herba yang produknya berupa susu tidak memiliki efek samping yang merugikan bagi kesehatan manusia bila dikonsumsi.

4. Telah dilakukan pelatihan peningkatan pengetahuan peternak dalam pencegahan penyakit mastitis dan penanganan induk sap perah mastitis, penyusunan konsentrat yang engolahan limbah organik.

\section{Khalayak Sasaran}

Adapun kelompok sasaran Program Pengabdian yaitu 21 orang peternak sapi perah yang tergabung dalam kelompok sapi perah "ANJASMORO AGR LESTARI" dengan kepemilikan lebih dari 163 eko induk berlokasi di Desa Pandesari Kecamatan Pujo yang merupakan wilayah kerja dari Koperasi Susu Pujon.

\section{Cara Pemecahan Masalah}

Untuk pemecahan permasalahan yang dihadap kelompok peternak sapi perah desa Pandesari agar tercapai tujuan yang telah direncanakan, menggunaka metode sebagai berikut :

a. Metode Ceramah dan Diskusi :

Metode ini dipilih untuk menyampaikan beberap aspek yang meliputi: manajemen usaha sapi perah secara umum, penyajian mineral sapi perah, penanganan penyakit mastitis, penggunaan obat susu, potensi dan permasalahan dalam usaha sap perah serta usaha dan kegiatan untuk mengatas permasalahan dalam upaya meningkatkan poten kelompok ternak dan produksi susu sapi perah di anggota kelompok peternak sapi perah Desa

b. Metode Demonstras

Mendemonstrasikan kegiatan-kegiatan yan bersifat aplikatif yang secara langsung dapat disaksika dan dicobakan oleh seluruh anggota kelompok peternak Desa Pandesari pada suatu tempat yang telah ditentukan. Misalnya: cara mencampur mineral dengan pakan lain, cara pengobatan penyakit mastitis, pembuatan sampai pengemasan obat mastiti berbahan baku herbal.

\section{c. Metode Pendampingan}

Pendampingan terhadap kelompok peternak sap perah Desa Pandesari dengan mendatangi langsung peternak pada saat peternak melakukan kegiatan beternaknya di kandang masing-masing. mastitis berbahan baku herbal, biosecurity, produks Pandesari Kecamatan Pujon.

\section{Rancangan Evaluas}

Evaluasi terhadap keberhasilan kegiatan pengabdian pada kelompok peternak sapi pera $\mathrm{D}$ Pandesari dilakukan dengan berpedoman pada :

a. Kesesuaian topik yang dikerjakan dengan kebutuhan peternak sapi perah.

b. Tingkat partisipasi, sikap dan tanggapan dari peternak terhadap kegiatan dan kesungguhan menerapkan keterampilan yang diperoleh dalam usaha sapi perah.

b. Setelah menerapkan pengetahuan dan keterampilan yang diperoleh kemudian dilakukan evaluasi terhadap keberhasilan usaha peternak.

\section{HASIL DAN PEMBAHASAN}

\section{Tahap Persiapan dan Perencanaan}

Pada tanggal 07 Januari 2012 dilaksanakan kontak awal dengan Ketua Kelompok sapi Perah “Anjasmoro Agri Lestari” untuk mengetahui profil kelompok ternak, potensi dan persoalan yang dihadapi setiap harinya sekaligus untuk menentukan lokasi yang tepat untuk melaksanakan kegiatan pengabdian. Dari hasil pertemuan awal, maka terdapat beberapa hal yang harus disiapkan terlebih dahulu sebelum pelaksanaan pengabdian.

Adapun hal-hal yang dipersiapkan oleh Tim pendamping pengabdian antara lain :

1. Materi penyuluhan dan pendampingan yang meliputi : a) Bawang Putih sebagai Obat Herbal, b) Pencegahan Penyakit Mastitis dan Kecacingan, c) Manajemen Pemeliharaan Sapi Perah secara Intensif, d) Peranan Mineral untuk Ternak Ruminansia, e) Seleksi pada Sapi Perah dan f). Pengolahan Limbah Ternak sebagai Pupuk Organik.

2. Pengadaan alat dan bahan untuk : Pembuatan minyak bawang putih, obat antimastitis dan kecacingan berbahan herbal, pengadaan mineral supra dan pengolahan limbah ternak sebagai pupuk organik.

3. Merancang pertemuan rutin dan pertemuan lapang. Kegiatan meliputi acara diskusi secara rutin setelah penyuluhan dan pelatihan dilaksanakan. Pertemuan lapang diisi dengan kegiatan praktek pembuatan minyak bawang

Sujono ${ }^{1}$ Lili Zalizar ${ }^{2}$ Ahmad Yani ${ }^{3}$ \& Suyatno ${ }^{4}$ Pendampingan Dan Pemanfaatan Herbal Untuk 39 Meningkatan Produksi Dan Kualitas Susu Sapi Perah 
putih, cara penggunaan obat anti mastitis dan kecacingan berbahan herbal, penggunaan mineral supra dan pengolahan limbah ternak sebagai pupuk organik

4. Merencanakan monitoring dan evaluasi kegiatan untuk memastikan bahwa program pendampingan telah berjalan sesuai dengan harapan.

5. Pelaporan kegiatan sesuai dengan hasil pendampingan pada kelompok peternak sapi perah Desa Pandesari.

Tabel 1. Pelaksanaan Program Pendampingan 2012

\begin{tabular}{|c|c|c|c|}
\hline No & Uraian Kegiatan & Tanggal Pelaksanaan & Jumlah Peserta \\
\hline 1 & $\begin{array}{l}\text { Kontak awal dengan ketua kelompok } \\
\text { peternak sapi perah ANJASMORO } \\
\text { AGRI LESTARI" }\end{array}$ & 07 Januari 2012 & 4 orang \\
\hline 2 & $\begin{array}{l}\text { Sosialiasai Rencana Program } \\
\text { Pendampingan oleh Tim DPPM }\end{array}$ & 12 Januari 2012 & 7 orang \\
\hline 3 & $\begin{array}{l}\text { Pengadaan Mineral untuk mengatasi } \\
\text { kelumpuhan pada induk baru } \\
\text { melahirkan }\end{array}$ & 26 Januari 2012 & 4 orang \\
\hline 4 & Pembuatan Minyak Bawang Putih & 2 Pebruari 2012 & 8 orang \\
\hline 5 & $\begin{array}{l}\text { Penyuluhan dan Pendampingan : } \\
\text { Pencegahan Penyakit Mastitis dan } \\
\text { Kecacingan } \\
\text { Manajemen Pemeliharaan Sapi perah } \\
\text { secara Intensif } \\
\text { Peranan Mineral Untuk Ternak } \\
\text { Ruminansia }\end{array}$ & 06 Pebruari 2012 & 29 orang \\
\hline 6 & $\begin{array}{l}\text { Pendampingan Penggunaan Mineral } \\
\text { untuk induk menjelang melahirkan dan } \\
\text { Minyak Bawang Putih untuk } \\
\text { mencegah kecacingan }\end{array}$ & 11 Pebruari 2012 & 29 orang \\
\hline 7 & $\begin{array}{l}\text { Pelatihan Pembuatan Minyak Bawang } \\
\text { Putih: Oleh Dr. Drh. Lili Zalizar, M.S. }\end{array}$ & 05 Maret 2012 & 20 orang \\
\hline 8 & $\begin{array}{l}\text { Pelatihan Penggunaan minyak bawang } \\
\text { putih pada Sapi Perah : Oleh Dr. Drh. } \\
\text { Lili Zalizar, M.S. }\end{array}$ & 13 Maret 2012 & 24 orang \\
\hline 9 & $\begin{array}{l}\text { Pelatihan dan Pendampingan } \\
\text { memilih bibit sapi perah yang } \\
\text { memiliki potensi genetik baik : } \\
\text { Oleh Ir. Suyatno, M.Si. }\end{array}$ & 20 Maret 2012 & 21 orang \\
\hline 10 & $\begin{array}{l}\text { Teori dan Pelatihan Pengolahan } \\
\text { Limbah Ternak menjadi Pupuk } \\
\text { Organik Guna Menciptakan } \\
\text { Lingkungan Kandang Yang Bersih dan } \\
\text { Sehat : Oleh Ir. Ahmad Yani, M.P. }\end{array}$ & 30 Maret 2012 & 23 orang \\
\hline 11 & $\begin{array}{l}\text { Evaluasi seluruh kegiatan pelatihan } \\
\text { dan pendampingan berkelanjutan }\end{array}$ & 09 April 2012 & 4 orang \\
\hline 12 & Pelaporan & 7 Juli 2012 & 4 orang \\
\hline
\end{tabular}

40 |Dedikasi, Volume 9, Mei 2012: 36 - 46
Kontak awal dengan ketua kelompok bertujuan mendapatkan informasi awal jumlah peternak sapi perah anggota kelompok "Anjasmoro Agri Lestari" desa Pandesari yang ikut dalam program pendampingan. Hasil kontak awal menyepakati antara lain akan dilaksanakan penyuluhan dan pendampingan pada kelompok peternak sapi perah sapi perah Desa Pandesari sejumlah 20 peternak dan dilaksanakan sosialisasi program kegiatan.

Sosialisasi program pengabdian diselenggarakan di rumah ketua kelompok ternak dihadiri oleh 7 orang peternak dan 4 orang pelaksanan program. Hasil sosialisasi dirumuskan beberapa harapan peternak untuk dilaksanakan penyuluhan dan pendampingan terutama berhubungan dengan kasus-kasus yang terjadi pada ternak yang mereka pelihara antara lain : sering timbul kelumpuhan pada induk baru lahir, kejadian mastitis dan kecacingan yang tinggi, mahalnya obat untuk perawatan dan pengobatan ternak, produksi susu dan harga susu yang rendah serta lingkungan kandang dan ternak yang kurang bersih.

\section{Bawang Putih sebagai Obat Herbal}

Beberapa di Indonesia, penggunaan bawan putih untuk jamu tradisional dan penyedap masaka sudah turun temurun dilakukan, terutama di daerah pedesaan. Di Sumatera Selatan, bawang putih dipakai dalam pembuatan saus empek-empek. Sebagian penjual jamu "gendongan" diceritakan bahwa, makan bawang putih satu siung 2 kali seminggu seusai makan siang, dapat membangkitkan gairah badan yang lesu, serta lebih tahan terhadap ancaman berbagai penyaki. Pengobatan tradisional akhir-akhir ini sudah menggunakan campuran bawang putih. Alasannya bawang putih telah diketahui bisa menangkal/ menyembuhkan banyak penyakit: TBC, influenza, anti diabetes, menurunkan tekanan darah tinggi, mengoba uka bakar, rematik, mencegah keracunan hati, anti kolesterol, dan sebagainya.

Manfaat, cara pembuatan minyak bawang putih dan cara penggunaan bawang putih sebagai obat pada ternak disampaikan oleh Dr. Drh. Lili Zalizar, MS. Penyampaian materi dan praktek pembuatan minyak bawang putih sangat menarik diikuti oleh semu anggota kelompok ternak. Peternak tampak membutuhkan penjelasan lebih lanjut tentang manfaa dan cara penggunaan minyak bawang putih untuk mengobati berbagai penyakit pada ternak. Beberapa penjelasan yang disampaikan bahwa minyak bawang putih dapat mengobati luka pada kulit ternak dan menekan kecacingan apabila dikonsum

Penelitian yang dilakukan oleh Belman dkk. melaporkan bahwa zat "allicin" yang terkandung dalam bawang putih mampu mencegah timbulnya sel-sel tumor, juga menghambat pertumbuhan sel-sel kanker baik pada manusia maupun ternak. Lebih lanjut Dr. Drh Lili Zalizar, MS menjelaskan bahwa mekanisme dari efek pencegahan oleh minyak astiri bawang putih memberikan hasil yang nyata tentang pencegahan timbulnya kerusakan sel dan kecacingan yang berdampak pada meningkatnya ketahanan tubuh serta perbaikan produksi susu terutama pada sapi yang sedang laktasi.

Lebih lanjut Dr. Drh. Lili Zalizar, MS menjelaskan secara ringkas cara pembuatan Minyak Bawang Putih dan sekaligus mempraktekkan bersama-sama dengan anggota peternak peserta pendampingan, sebagai berikut :

1. Siap kan bawang putih, minyak goreng dan kompor

2. Bawang putih diblender sampai halus

3. Minyak goreng dipanaskan, masukkan bawang putih yang telah diblender

4. Dipanasi dengan api kecil sambil diaduk hingga kering

5. Minyak dipisahkan dengan padatan dengan cara diperas

6. Minyak bawang putih dimasukkan dalam boto

7. Diaplikasikan untuk obat pada beberapa ternak yang sedang sakit

Sewaktu mengakhiri penyuluhan dan pelatihan para peternak menyatakan kegembiraannya karen tentang cara membuat obat berbahan herbal dengan cara yang mudah dan murah namun memberikan efek yang sangat positif terhadap penyembuhan beberapa penyakit pada ternak yang mereka pelihara. Disamping itu dapat menekan penggunaan obat modern yang harganya mahal dan berdampak negatif bagi produks yang dihasilkan antara lain kandungan antibiotika.

Selain zat aktif allicin, unsur lain bawang putih ialah selenium adalah mineral mikro yang berperan mencegah terjadinya penggumpalan darah serta sebagai antioksidan, sehingga mampu mencegah terjadinya kerusakan sel tubuh. Disamping itu

Sujono ${ }^{l}$, Lili Zalizar ${ }^{2}$,Ahmad Yani ${ }^{3}, \&$ Suyatno ${ }^{4}$, Pendampingan Dan Pemanfaatan Herbal Untuk $\mid 41$ Meningkatan Produksi Dan Kualitas Susu Sapi Perah 
ditemukan adanya zat "anti hemolitic factor, berguna mencegah rusaknya persendian. Adapun zat "methyllalyl trisulfide" dalam bawang putih berguna untuk mencegah perlengketan sel-sel darah merah (Anonim, 2010).

\section{Mastitis dan Kecacingan}

\section{Penyakit Mastitis dan Penanganannya}

Kerugian dalam usaha sapi perah salah satunya disebabkan oleh gangguan penyakit terutama mastitis. Faktor penyebab gangguan dapat bersifat internal maupun eksternal. Faktor internal misalnya gangguan hormonal, kelainan genetik pada individu ternak itu. Sedangkan faktor eksternal itu disebabkan penanganan sebelum dan setelah pemerahan yang tidak higienis, lingkungan kandang yang kotor sampai pemerah yang tidak mengikuti standar operasional prosedur dalam pemerahan (SOP)

Mastitis digolongkan dalam dua jenis, yakni mastitis bacterial dan mastitis mikotik. Mastitis bakterial disebabkan oleh berbagai jenis bakteri yang umumnya adalah Streptococcus dan Staphylococcus; sedangkan mastitis mikotik disebabkan oleh beberapa jenis cendawan terutama dari golongan ragi-ragian (khamir)

Sapi perah laktasi yang terinfeksi mastitis bacterial, mula-mula ditandai dengan perubahan susu. Susu berubah menjadi encer dan pecah dengan uji alkohol, susu bergumpal dan kadang-kadang bercampur darah ataupun nanah. Tanda-tanda selanjutnya sebagai berikut:

1. Ambing panas, membengkak dan meradan

2. Nafsu makan menurun, sehingga kondisi tubuh menurun pula

3. Produksi susu mengalami penurunan.

Materi pencegahan dan penanganan penyakit mastitis disajikan oleh Dr. Drh. Lili Zalizar, MS. Mengenai faktor penyebab mastitis, tingkat/stadium penyakit mastitis, dampak kerugian ekonomi penyakit mastitis dan lain-lain. Sanitasi kandang dan lingkungan yang baik diharapkan dapat mencegah timbulnya penyakit yang menyebabkan mastitis dan penyakit lainnya. Keberhasilan usaha peternakan sangat ditentukan oleh keterpaduan dari segi bibit ternak, pakan, dan manajemen dalam arti luas.

42 |Dedikasi, Volume 9, Mei 2012:36- 46
Selanjutnya peternak peserta pendampingan diberikan pengetahuan tentang penggunaan obat sale berbahan baku herbal yang merupakan produk dar penggunaan salep anti mastitis selama sekitar 2 bula menunjukkan adanya perubahan yang sangat nyata terhadap penurunan kejadian mastitis dan penyembuhan mastitis pada sapi perah yang dimilik peserta pendampingan. Salep anti mastitis memberikan dampak positif terhadap kesehatan mbing, peningkatan produksi susu dan yang akhirnya berdampak pada peningkatan pendapatan peternak sapi perah angggota kelompok peternak "Anjasmoro Agri Lestari” di Desa Pandesari.

\section{Kecacingan}

Berdasarkan pengamatan, anggota peternak Desa Pandesari sangat antusias mendengarkan penjelasan tentang penyebab, gejala, dampak dan car pengobatan kecacingan. Sebelum kegiatan penyuluhan Kecacingan, Tim pendamping mengawali terlebih dahulu dengan penyampaian tentang faktor-faktor sebagai pemicu atau penyebab kecacingan pada ternak terutama kondisi kandang yang kurang bersih, cara penyajian pakan yang sehat. Selanjutnya dijelaskan entang dampak yang ditimbulkan akibat kecacingan, cara pencegahan dan pengobatan ternak yang dipelihara. Pencegahan dan pengobatan kecacingan dapat dilakukan dengan obat-obat kimia dan juga obat herbal, salah satu obat herbal untuk mencegah dan mengobati kecacingan adalah bawang putih.

Penyuluhan kecacingan dilakanakan di rumah Ir

Ali Mahmud Dusun Sebaluh dilaksanakan 6 Pebruar

2011 dan dihadiri 29 orang peternak sapi perah, di akhir penyuluhan dilanjutkan diskusi tentang beberapa penyakit yang menyerang sapi perah dan peternak berharap Tim pengabdi akan melaksanakan pendampingan selanjutnya.

Kecacingan juga menyerang pedet sapi perah yaitu gangguan parasit cacing pada usus. Salah satu enis parasit usus yang sering dilaporkan menyerang pedet muda adalah toxocariasis. Cacing ini menimbulkan kerugian pada peternak cukup besar, arena dapat mengakibatkan kematian pada pedet. Pengendalian kecacingan kurang diperhatikan oleh peternak disebabkan gejalanya tidak tampak jelas tap menghambat pertumbuhan dan perkembangan pedet.

\section{Mineral untuk Sapi Perah}

Mineral memang dibutuhkan dalam jumlah yang sangat sedikit dibandingkan dengan zat gizi yang lain namun mineral sangat penting untuk sapi perah terutama yang sedang laktasi. Mineral dibutuhkan sap perah untuk kebutuhan hidup pokok, pertumbuhan dan produksi susu.

Penyuluhan dan pendampingan penggunaan mineral pada sapi perah disampaikan oleh Prof. Dr Sujono. Selama kegiatan dijelaskan bahwa mineral yang disajikan pada ternak sapi perah harus sesuai dengan kebutuhan sapi perah agar sapi tidak mengalami kelumpuhan dan produksi susu tetap tinggi. Mineral secara alamiah telah tersedia pada pakan yang disajikan namun tidak dalam jumlah yang mencukupi kebutuhan ternak terutama sapi perah yang sedang produksi susu tinggi, sebab kekurangan jumlah minera pada ternak sapi dapat menyebabkan meningkatnya insiden penyakit, produksi yang rendah, dan laju pertumbuhan yang menurun pada sapi dara. Defisiens mineral makro dalam jumlah yang sedikit saja dapa menurunkan kekebalan ternak sapi dan kemampua untuk melawan infeksi, seperti pada penyakit mastitis dan penyakit lainnya. Penurunan kekebalan dijumpa sebelum penurunan produksi atau beberapa kelaina akibat defisiensi, seperti perubahan warna bulu.

Lebih lanjut Prof. Dr. Sujono menjelaskan bahwa untuk kebutuhan mineral sapi perah yang sedan berproduksi susu yang perlu diperhatikan adalah kecukupan unsur Ca, P dan Mg. Kebutuhan minera $\mathrm{Ca}$ dan $\mathrm{P}$ untuk pokok hidup sapi perah dengan bobot badan 300 s.d. $500 \mathrm{~kg}$ berkisar masing-masing 6.8 s.d. $10.4 \mathrm{gr} / \mathrm{ekor} / \mathrm{hari}$ sedangkan kebutuhan Ca untuk tiap liter produksi susu 2.0 gram dan $\mathrm{P}$ untuk tiap liter produksi susu 1.5 gram (Siregar, 2004), oleh karena itu mineral merupakan salah komponen penting yang harus diperhatikan dalam usaha peternakan terutam sapi perah.

Setelah selesai kegiatan penyuluhan dilanjutkan pembagian mineral masing-masing $5 \mathrm{~kg}$ kepada peserta anggota kelompok peternak "Anjasmoro Agri Lestari" sebanyak 29 orang. Mineral yang dibagikan adalah produksi dari Prof. Dr. Sujono dan sekaligus dijelaskan tentang cara penyajian serta manfaatnya bagi ternak sapi perah.

\section{Seleksi Pada Ternak}

Penyuluhan dengan materi seleksi pada sapi perah disampaikan oleh Ir. Suyatno, M.Si. Materi disajikan secara runtun, singkat dan jelas. Kegiatan budidaya ternak diarahkan pada usaha agribisnis yang menguntungkan dan berpeluang untuk dikembangkan, karena konsumsi produk peternakan khususnya susu diyakini akan terus meningkat sebagai konsekuensi logis dari pertumbuhan jumlah penduduk, meningkatnya pengetahuan, dan kesadaran masyarakat akan kebutuhan gizi, meningkatnya endapatan dan tingkat kesejahteraan masyarakat.

Lebih Lanjut Ir. Suyatno, M.Si. menjelaskan bahwa seleksi diarahkan untuk memilih bibit-bibit ternak yang memenuhi kriteria/standar yang ditetapkan untuk dipelihara lebih lanjut baik sebagai induk maupun sebagai pejantan sapi perah unggul sedangkan culling adalah mengeluarkan bibit-bibit/ ternak yang telah dipelihara untuk dijual atau dipelihara untuk tujuan penggemukan yang selanjutnya dijua karena tidak layak lagi dipelihara sebagai ternak perah karena tidak menguntungkan.

Seleksi bibit ternak sapi dengan tujuan pengembangbiakan sapi perah dengan harapan untuk mendapatkan keturunan yang unggul. Seleksi tergantung pada selera (preverensi) peternak dan kemampuan modal yang dimiliki. Konsekuensi seleksi ternak membutuhkan modal yang banyak karen kondisi ternak dalam kategori exelent. Faktor penunjangnya adalah pertumbuhan dan perkembangan bibit sapi perah yang dipelihara lebih cepat dari pada fase pertumbuhan bibit sapi perah pada umumnya.

Peningkatan kualitas bibit ternak sapi perah dapa dicapai dalam waktu singkat dengan sistem kawin suntik (inseminas akan dapat memperbaiki mutu genetik ternak dan menghasilkan bibit ternak sapi perah yang berkualitas bagus hanya dalam waktu singkat (Warwick, et.al., 1990). IB dilakukan dengan menggunakan pejantan unggul yang dikawinkan secara berulang dengan keturunannya hingga F3.

\section{Organik}

Untuk mengatasi pencemaran lingkungan yang berdampak pada kesehatan lingkungan dan manusia 
maka perlu pengelolaan limbah secara bijaksana melalui proses pengolahan dengan teknologi fermentasi untuk mendapatkan pupuk organik disatu sisi dan kesehatan lingkungan di sisi lain. Dengan proses fermentasi limbah ternak dapat diubah dalam waktu singkat menjadi pupuk organik yang dapat memberikan dampak yang posistif bagi rehabilitasi lahan pertanian yang telah mengalami kerusakan parah akibat penggunaan pupuk kimia dan pestisida kimia dalam jangka panjang.

Materi pengolahan limbah ternak disajikan oleh Ir. Ahmad Yani, MP. Meliputi dampak negatif limbah ternak yang tidak diolah, proses pengolahan limbah ternak, dampak positif penggunaan pupuk organik bagi tanah dan tanaman dalam waktu jangka panjang,

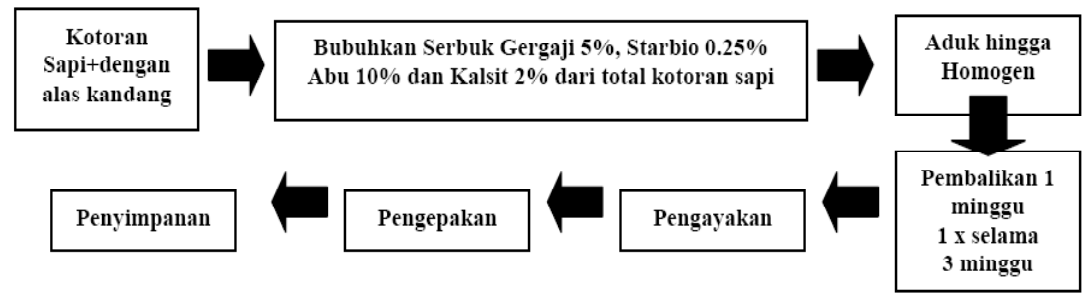

Gambar1. Proses pembuatan pupuk organik padat
Setelah selesai pelatihan peternak berharap agar produksi pupuk organik dilaksanakan dalam skala besar untuk dijual sehingga dapat dijadikan sumber penghasilan bagi kelompok peternak.

1. Kelompok peternak Sapi Perah "ANJOSMORO AGRI LESTARI" yang berlokasi di desa Pandesari memiliki potensi yang besar untuk dikembangkan dan perlu untuk dibenahi terutama dalam hal sering timbulnya kejadian penyakit dan terjadi kelumpuhan terutama pada ternak yang produksi susunya tinggi.

2. Penyuluhan, pelatihan dan pendampingan dalam usaha sapi perah di desa Pandesari sangat yang tinggi berharap untuk dilaksanakan secara berkelanjutan.

3. Kelompok peternak sapi perah desa Pandesari menyadari bahwa kegiatan ini akan memberikan

\section{KESIMPULAN DAN SARAN} dinantikan oleh peternak dan dengan kesadaran

44 |Dedikasi, Volume 9, Mei 2012: 36 - 46
Disamping itu sanitasi kandang dan lingkungan yang baik diharapkan dapat mencegah timbulnya penyakit yang menyebabkan mastitis dan penyakit lainnya. Keberhasilan usaha peternakan salah sutu andang dalam arti luas.

Bahan-bahan yang disiapkan untuk pembuatan pupuk organik meliputi : $1000 \mathrm{~kg}$ . gergaji, $2.5 \mathrm{~kg}$ Probiotik, $20 \mathrm{~kg}$ Kalsit, Adapun cara embuatan pupuk organik padat mengikuti tahapan sebagai berikut :

\section{dampak bagi perbaikan penghasilan peternak} sehingga terbangun motivasi tinggi untuk meneruskan kegiatan usaha sapi perah sebagai tumpuan harapan yang masih menjanjikan keuntungan.

4. Manajemen usaha sapi perah semakin membaik, terjadi penurunan kejadian kelumpuhan pada sapi produktif mencapai $50 \%$ dan kejadian mastitis menurun sampai $70 \%$.

5. Pendampingan manajemen usaha sapi perah, pelatihan penyajian mineral seimbang, serta penanganan penyakit mastitis dengan obat berbahan baku herbal memberikan harapan bag peningkatan kesehatan dan produktifitas sap perah yang bermuara pada perbaikan pendapatan peternak sapi perah di desa Pandesari.

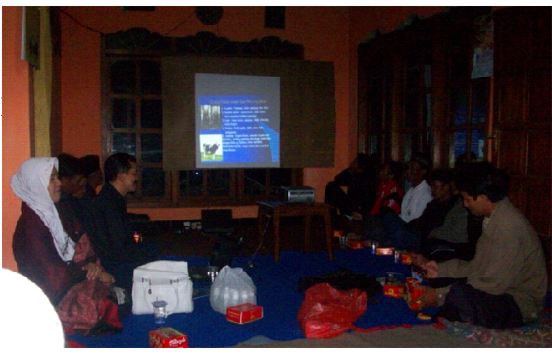

Gambar 2. Sosialisasi Rencana Program, Penyuluan dan Pendampingan
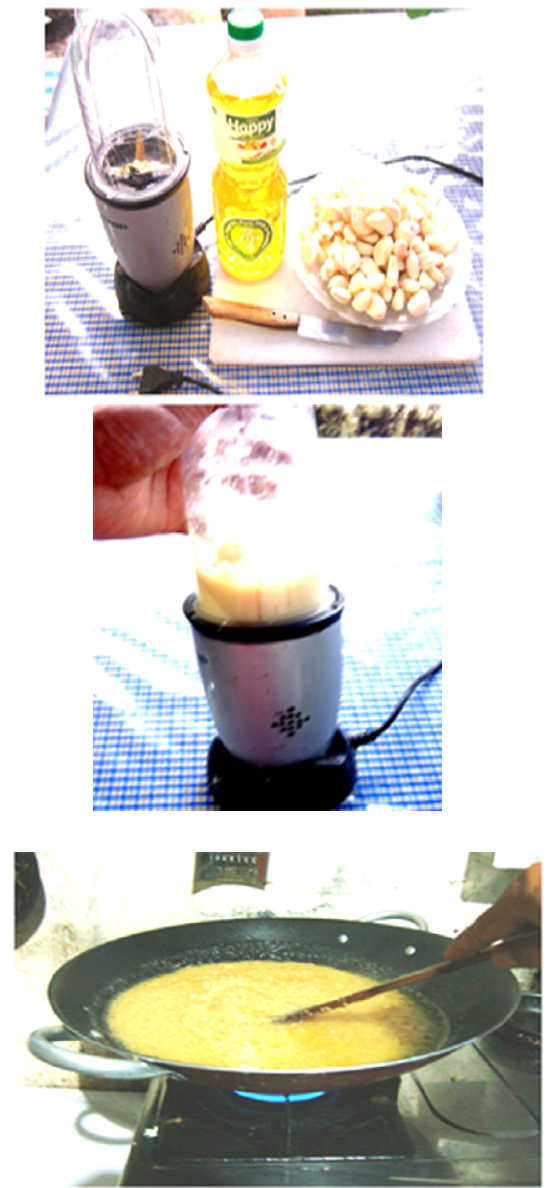

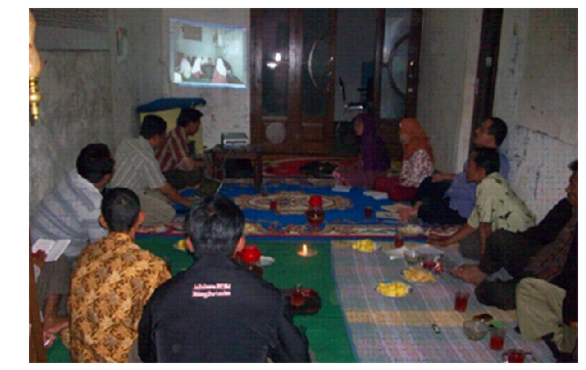

Gambar 4. Pendampingan Penguatan

Kelompok dan Jejaring Pemasaran

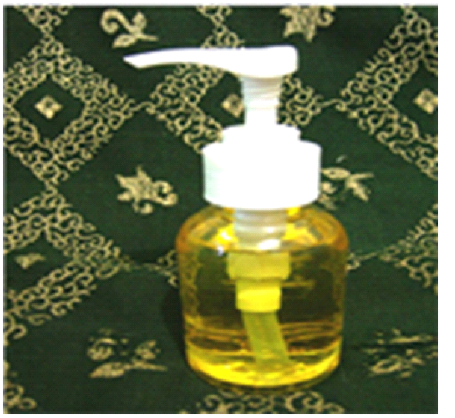

Gambar 3. Proses pembuatan minyak bawang putih
Sujono ${ }^{1}$, Lili Zalizar ${ }^{2}$, Ahmad Yani $^{3}$, \& Suyatno ${ }^{4}$, Pendampingan Dan Pemanfaatan Herbal Untuk $\mid \mathbf{4 5}$ Meningkatan Produksi Dan Kualitas Susu Sapi Perah 


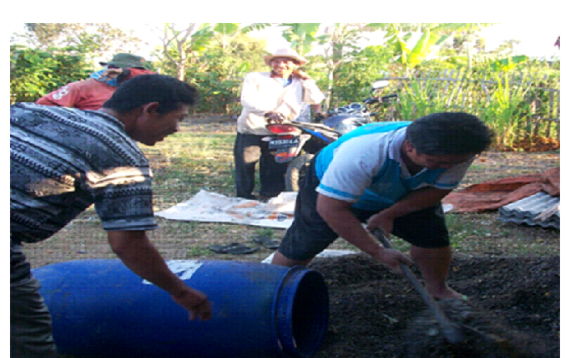

Gambar 5. Pelatihan Pembuatan Pupuk Organik

\section{DAFTAR PUSTAKA}

Anonymous, 2000. Pengobatan Mastitis yang Efektif. http://vet-indo.com/.

Anonim, 2007. Program Breeding Sapi Perah. Ditjen Peternakan Jakarta.

Anonymous , 2010. Penyakit pada Ternak Sapi Perah dan Sapi Potong.http://smallcrab.com.

Anonymous, 2011. Sanitasi dan Kesehatan Ternak. http://ojimori.com/.

Arif, dkk. 2009. Manajemen Kesehatan Pemerahan. http://disnak.jabarprov.go.id/.

Arifianto dan Liviawaty, 2000. Pengendalian Hama dan Penyakit Ternak. UI Press Jakarta.

Baharudin, 2010. Mastitis Pada Ternak Sapi. http:/ balitvet.litbang.deptan.go.id/.Hidayat,

Dharmojono, 1995. Rempah-rempah untuk Ternak. Penebar Swadaya Jakarta.

Luthvin Paramitha. 2007. Identifikasi Staphylococcus aureus Penyebab Mastitis dengan Uji Fermentasi Mannitol dan Deteksi Produksi Asetoin pada Sapi Perah Di Wilayah Kerja Koperasi Usaha Tani Di Wilayah Kerja Koperasi Usaha Tani
Ternak Suka Makmur Grati Pasuruan http://digilib.unair.ac.id/.

46 |Dedikasi, Volume 9, Mei 2012: 36 - 46
Siregar S.B, 2004. Ransum Ternak Ruminasia Penebar Swadaya.

Toehihere M., 1988. Penanganan Limbah Pangan. Ditjen Pertanian Jakarta.

Warwick E.J., Astuti J.M. dan Hardjosubroto W., 1990. Pemulian Ternak Gajah Mada University, Yokyakarta.

Wijayani, Cinthya. 2007. Streptococcus agalactiae http://farmasi.sanatadharma.ac.id/.

Yatim W., 1983. Genetika. Tarsito, Bandung. 